\title{
Impact of a variable number tandem repeat in the CYP2C9 promoter on warfarin sensitivity and responsiveness in Jordanians with cardiovascular disease
}

This article was published in the following Dove Medical Press journal: Pharmacogenomics and Personalized Medicine

\author{
Laith N AL-Eitan ${ }^{1,2}$ \\ Ayah Y Almasri' \\ Sahar O Al-Habahbeh' \\ 'Department of Applied Biological \\ Sciences, Jordan University of Science \\ and Technology, Irbid 22 I 10, Jordan; \\ ${ }^{2}$ Department of Biotechnology and \\ Genetic Engineering, Jordan University \\ of Science and Technology, Irbid \\ 22110 , Jordan
}

Purpose: The purpose of this study was to investigate the influence of $\mathrm{CYP} / \mathrm{CYP} 4502 \mathrm{C} 9$ (CYP2C9) promoter variable number tandem repeat (p-VNTR) polymorphism on susceptibility to cardiovascular disease and on warfarin sensitivity and responsiveness, in Jordanians with cardiovascular disease during initiation and stabilization phases of therapy.

Patients and methods: A total of 211 cardiovascular patients who were being treated with warfarin anticoagulants and 205 healthy individuals were enrolled in this study. PCR-based methods were performed to analyze the effects of $C Y P 2 C 9 \mathrm{p}$-VNTR polymorphism on warfarin metabolism. The $\mathrm{p}$-VNTR polymorphism was composed of tandem repeat motifs sorted into three alleles based on the length and structure: short (p-VNTR-S), middle (p-VNTR-M), and long (p-VNTR-L).

Results: We found that the genotypic and allelic frequencies differ significantly between patients and healthy individuals; therefore, our results suggest that this polymorphism is associated with cardiovascular disease in the Jordanian population. Moreover, during the initiation phase of therapy, $20 \%$ of warfarin-sensitive patients were homozygous for a short allele (p-VNTR-S), and $12.2 \%$ were heterozygous for this allele (p-VNTR-M/p-VNTR-S). During the stabilization phase, no significant differences were found between these groups and their genotypic frequencies. Additionally, we did not confirm any relationship between the $C Y P 2 C 9 \mathrm{p}-\mathrm{VNTR}$ polymorphism and warfarin response during either the initiation or the stabilization phases of therapy. Conclusion: Our data show a significant difference between the $C Y P 2 C 9$ p-VNTR polymorphism and risk of cardiovascular disease, in addition to significant association between this polymorphism and sensitivity to warfarin at the initiation phase of therapy in a Jordanian population. However, there is no correlation between this polymorphism and warfarin response, international normalized ratio (INR) values, or required warfarin dose to achieve a target INR either at the initiation or stabilization phases of therapy. To further corroborate our results, additional studies are required with a larger number of samples and different ethnic groups.

Keywords: warfarin, CYP2C9 promoter variable tandem repeat, polymorphism, cardiovascular disorder, oral anticoagulant, INR, warfarin dosage

\section{Introduction}

Warfarin is an oral anticoagulant prescribed for the prevention and treatment of thrombotic disorders and is indicated for thrombotic disorders such as atrial fibrillation, heart valve replacement, history of thrombosis, and post-orthopedic surgery. ${ }^{1}$ It is clinically 
available as a racemic mixture of $\mathrm{R}$ and $\mathrm{S}$ isomers, where the $\mathrm{S}$-isoform has a potent activity $2-5$ times higher than the $\mathrm{R}$-isoform and is metabolized mainly by the CYP/CYP450 2C9 enzyme (CYP2C9) in the liver. ${ }^{1,2}$

The ability of warfarin to act as an anticoagulant stems from its deactivation of the vitamin $\mathrm{K}$ epoxide reductase $\mathrm{C}$ complex (VKORC1), regenerating the reduced form of vitamin $\mathrm{K}$ that is necessary for the activation of coagulation factors. ${ }^{1,3,4}$ The efficacy and safety of warfarin depend mainly on the maintenance of prothrombin time, represented by the international normalized ratio (INR), within the therapeutic range. Analysis of many studies has shown that higher INR values are related to an increased risk of hemorrhage, while a lower INR value leads to a high risk of thromboembolism or stroke. ${ }^{5-8}$ However, reaching the target INR may take weeks, increasing the risk of adverse drug events during the initial phase of therapy. ${ }^{9}$

Knowing the extent to which genetic and environmental factors affect the anticoagulant response might help predict more individualized warfarin doses, resulting in a more accurate and safe anticoagulation therapy. ${ }^{10}$ In the late 2000 s, the United States Food and Drug Administration announced that the warfarin label stat (which describes patients' therapeutic dosage) had to underline its pharmacogenetic activity, particularly in patients with $V K O R C 11,639 \mathrm{G}>\mathrm{A}, C Y P 2 C 9$ * 2, and CYP2C9 * 3 polymorphisms. ${ }^{11-13}$

Polymorphisms in genes encoding metabolic enzymes, transporters, and drug receptors can modulate warfarin response. ${ }^{14}$ Correspondingly, pharmacogenetic analysis of two genes, CYP2C9 and VKORC1, suggests that their genetic variants strongly influence the individual response to warfarin. ${ }^{3} C Y P 2 C 9$ metabolizes almost $25 \%$ of all clinical medications, and genetic variation in $C Y P 2 C 9$ gene can have a significant effect on the outcome of treatment, particularly for drugs with a narrow therapeutic index like warfarin. ${ }^{15}$

In humans, CYP2C9 gene has been mapped to chromosome 10q24.2 and covers $>55$ kilobases (kb). ${ }^{16,17}$ Polymorphisms of CYP2C9 coding region have been extensively studied, and over 30 alleles have been recognized. ${ }^{18}$ The most common $C Y P 2 C 9$ allele, $C Y P 2 C 9 * 1$, is considered to be a wild-type genotype, whereas the CYP2C9*2 and * 3 alleles involve the single-nucleotide polymorphisms (SNPs) of Arg144Cys and Ile359Leu, respectively. Both the CYP2C9 * 2 and * 3 alleles play an important role in the metabolic activity of warfarin. ${ }^{19}$

In the promoter region of $C Y P 2 C 9$, a variable number tandem repeat (VNTR) polymorphism is located $4 \mathrm{~kb}$ upstream from the translation site, affecting the expression of $C Y P 2 C 9$
mRNA in human liver. Three types of fragments were detected: short allele (p-VNTR-S) (417-438 bp), medium allele (p-VNTR-M) (446-488 bp), and long allele (p-VNTRL) (512-522 bp). Of these fragments, p-VNTR-S has been found to decrease the activity of allelic promoters and, in turn, mRNA expression. ${ }^{20}$ These VNTR polymorphisms can regulate gene expression in a number of ways: inhibiting or promoting gene expression by modifying transcription factors or other binding site proteins; and change in the structure of the DNA, such as the variation in the distance between the functional units. ${ }^{21,22}$ VNTR polymorphisms often have an effect on gene expression as well as the increased risk of disease. ${ }^{23-28}$

The goal of the present study was to demonstrate the effects of $C Y P 2 C 9$ (pVNTR) polymorphism on the risk of cardiovascular disease and the variability of warfarin dose requirements and sensitivity. Consequently, this study contributes to efforts to individualize dosing regimens in the Jordanian population.

\section{Patients and methods Subjects}

Ethical approval for this study was obtained from the Human Research Committees at Jordan University of Science and Technology in Irbid and the Royal Medical Services in Amman. This study was also conducted in accordance with the Declaration of Helsinki. All patients were recruited from anticoagulation clinics within the Queen Alia Heart Institute in Amman, after they gave their written informed consent. Patients taking CYP2C9-inducing drugs or those receiving concomitant treatment known to interact with warfarin or recorded clinical data lost, pregnant women, and alcohol abuse were excluded. In total, 416 subjects (205 healthy controls free of any cardiovascular disease and 211 cardiovascular patients) who were aged $\geq 18$ years, who had been receiving warfarin for at least 3 months, and who gave written approval were included in this study.

\section{Data collection and follow-up time}

The blood samples were collected for the determination of the venous INR and p-VNTR of the CYP2C9 genotype. During patients' clinical visits, demographic data on gender, age, and body mass index were recorded, as well as indications for warfarin treatment, target INR (INR values were reviewed in medical records from January 2014 to November 2015), average weekly doses of warfarin required to reach the therapeutic INR, medical problems, and concurrent medications. In this study, the required warfarin dose and INR 
values were recorded in two stages: the first stage is at the beginning of the therapy and called initiation phase, and the second stage is when the INR values reach the stable point, where the INR values are within the therapeutic range for at least three consecutive visits and this stage is called the stabilization phase of therapy.

\section{Outcome measures}

The patients in this study were divided into two categories during the initiation and stabilization of therapy. The first category was sensitivity to warfarin according to Klein et al study (2009): ${ }^{29}$ patients in this category were defined as patients with resistance to warfarin needing a high dose of warfarin to reach therapeutic INR ( $>49 \mathrm{mg} /$ week), normal patients requiring an intermediate dose (21-49 mg/week), and sensitive patients needing a low dose of warfarin $(<21$ $\mathrm{mg} /$ week). Based on Higashi et al's (2002) study, ${ }^{30}$ the second category included response to warfarin and was subdivided into good responders (INR value within the therapeutic range), poor responders (INR value below the target), and ultra-responders (INR above the target range).

\section{Genotyping}

Leukocyte DNA was extracted with the Gentra Pure gene Blood kit according to the manufacturing protocols (Promega Corporation, Fitchburg, WI, USA). The concentration and purity of the extracted DNA were evaluated using the NanoDrop $1000^{\circledR}$ spectrophotometer.

DNA samples were amplified by PCR in a final volume of $25 \mu \mathrm{L}$, each with $1.5 \mu \mathrm{L}$ of primer, $2 \mu \mathrm{L}$ of genomic DNA, $12.5 \mu \mathrm{L}$ of master mix, and $9.5 \mu \mathrm{L}$ of nuclease-free water.

The sequences for the forward and reverse primers were 5'-TGTAGTCCCAGGTTGTCAAGAGG-3' and 5'-CCAGTCTCTGTCTTTTCATCTCATTC-3', respectively. ${ }^{20}$ The PCR conditions consisted of the initial denaturation at $95^{\circ} \mathrm{C}$ for 1 minute, 351 -minute cycles (denaturation at $94^{\circ} \mathrm{C}$, annealing at $60^{\circ} \mathrm{C}$, and extension at $72^{\circ} \mathrm{C}$ ) and a final 5-minute extension at $72^{\circ} \mathrm{C}$. Known genotype controls and DNA-free blank tubes were included with each batch of samples. The PCR products were visualized in 3\% polyacrylamide gels stained with ethidium bromide.

\section{Statistical analysis}

We used the Pearson chi-squared tests to assess the genetic association of p-VNTR and cardiovascular disease, and HardyWeinberg equilibrium (HWE) $P$-values for genotypic distribution were calculated via the Court lab-HW calculator. In order to assess which of the selected $C Y P 2 C 9 \mathrm{p}$-VNTR polymorphisms is associated with warfarin sensitivity and responsiveness, several statistical analyses of genetic correlation were carried out using SPSS version 21.0, including the chi-squared test and one-way ANOVA. Further, to study genotype-per-genotype association, we used post hoc multiple comparison test.

\section{Results}

\section{Patient characteristics}

A total of 211 warfarin intake patients agreed to participate in this study. These 211 patients were included in this study to evaluate the association of $C Y P 2 C 9$ ( $\mathrm{p}$-VNTR) genotype with increased risk of cardiovascular disease and its effect on the sensitivity and responsiveness of warfarin during the initiation phase of therapy in Jordanian population, of which only 132 patients reached the stabilization stage, and therefore, to evaluate the effect of this genotype on the sensitivity and responsiveness to warfarin during the stabilization phase of the therapy in Jordanian population.

Overall, $69.6 \%$ of the patients were good metabolizers, $15.2 \%$ were extensive metabolizers, and $15.2 \%$ were poor metabolizers. The mean age and the smoking status were found to differ significantly between these three groups, with $P=0.019$ and $P<0.0001$, respectively. Patient demographics, indications for anticoagulation therapy, and warfarin dose requirements for each group are shown in Table 1 . The mean age of the control $(n=205)$ was 37.3 with SD 13.8, 112 out of 205 were male and 67 were smokers.

\section{Genotypic and allelic frequencies}

All samples were genotyped for $\mathrm{p}$-VNTR polymorphism, which was previously reported to affect $C Y P 2 C 9$ enzyme activity. ${ }^{20}$ Regarding the length of $\mathrm{p}-\mathrm{VNTR}$ repeats in the $C Y P 2 C 9$ promoter region, five different genotypes were identified. The subjects were categorized into depending on whether they possessed the short ( $\mathrm{p}$-VNTR-S, 417-438 bp), medium ( $\mathrm{p}$-VNTRM, 446-488 bp), or long (p-VNTR-L, 512-522 bp) alleles.

These (p-VNTR) polymorphisms were in accordance with the HWE. Analysis of genotypes showed that there were seven $(3.3 \%)$ subjects with the homozygous LL genotype, $58(27.5 \%)$ subjects with the heterozygous ML genotype, five $(2.4 \%)$ subjects with the homozygous SS genotype, 82 (38.8) subjects with the heterozygous MS genotype, and 59 (28\%) subjects with the homozygous MM genotype (Table 2). Allelic and genotypic frequencies differed significantly between patients and controls (Table 2). The frequency of the MS genotype was $38.8 \%(82 / 211)$ in patients compared with $58.1 \%(119 / 205)$ in controls. Among the patients, the frequency of the ML genotype was $27.5 \%$ (58/211) compared 
Table I Demographics and clinical characteristics of 211 cardiovascular patients treated with warfarin at the Queen Alia Heart Institute

\begin{tabular}{|c|c|c|c|c|c|}
\hline Category & Subcategory & Poor metabolizer & Good metabolizers & Extensive metabolizers & $P$-value* \\
\hline \multirow[t]{6}{*}{ Demographics } & Patients (N, \%) & $(32 / 211) 15.2 \%$ & (147/2II) 69.6\% & $(32 / 21 \mathrm{I}) 15.2 \%$ & \\
\hline & $\mathrm{Age}^{\mathrm{a}}$, years [\%] & $57.2[17.1]$ & $54.7[14.8]$ & $47.2[14.7]$ & 0.019 \\
\hline & $\mathrm{BMI}^{\mathrm{a}}, \mathrm{kg} / \mathrm{m}^{2}[\%]$ & $28.1[6.2]$ & $27.8[4.9]$ & $27.6[3.5]$ & 0.732 \\
\hline & Smoking (N, \%) & (15/32) $46.9 \%$ & (42/I47) $28.6 \%$ & (16/32) $50.0 \%$ & $<0.0001$ \\
\hline & Male & $59.4 \%$ & $51.0 \%$ & $65.6 \%$ & 0.27 \\
\hline & Female & $40.6 \%$ & $49.0 \%$ & $34.4 \%$ & \\
\hline \multirow[t]{6}{*}{ Concomitant disease } & Comorbidity & $65.6 \%$ & $68.7 \%$ & $53.1 \%$ & 0.075 \\
\hline & Hypertension & $40.6 \%$ & $42.2 \%$ & $18.8 \%$ & 0.046 \\
\hline & Diabetes mellitus & $21.9 \%$ & $21.8 \%$ & $21.9 \%$ & 1.0 \\
\hline & $\mathrm{CHD}$ & $31.3 \%$ & $25.9 \%$ & $28.1 \%$ & 0.814 \\
\hline & Thyroid & $0 \%$ & $3.4 \%$ & $3.1 \%$ & 0.57 \\
\hline & Lipid & $3.1 \%$ & $6.8 \%$ & $3.1 \%$ & 0.55 \\
\hline Medication & Aspirin & $59.4 \%$ & $66 \%$ & $75 \%$ & 0.411 \\
\hline \multirow[t]{5}{*}{ Indication of treatment } & MVR & $18.8 \%$ & $12.9 \%$ & $21.9 \%$ & 0.163 \\
\hline & AVR & $6.3 \%$ & $23.8 \%$ & $21.9 \%$ & \\
\hline & $\mathrm{AF}$ & $37.5 \%$ & $17.7 \%$ & $18.8 \%$ & \\
\hline & DVR & $18.7 \%$ & $23.1 \%$ & $25.0 \%$ & \\
\hline & Others & $18.7 \%$ & $22.5 \%$ & $12.4 \%$ & \\
\hline \multirow[t]{2}{*}{ Target INR } & $2-3$ & $46.9 \%$ & $38.8 \%$ & $37.5 \%$ & 0.69 \\
\hline & $2.5-3.5$ & $53.1 \%$ & $61.2 \%$ & $62.5 \%$ & \\
\hline Mean INR ${ }^{a}$ & & $2.8[0.73]$ & $2.4[0.75]$ & $2.5[0.85]$ & 0.027 \\
\hline
\end{tabular}

Notes: *P-value $<0.05$ is considered significant. ${ }^{a}$ Mean SD in square brackets.

Abbreviations: AF, atrial fibrillation; AVR, aortic valve replacement; BMI, body mass index; CHD, chronic heart disease; DVR, double valve replacement; INR, international normalized ratio; MVR, mitral valve replacement.

Table 2 Allelic and genotypic frequencies for the P-VNTR polymorphism, in 205 controls and 2II Jordanian cardiovascular patients

\begin{tabular}{|l|l|l|l|l|}
\hline Genotype and allele & Patients & Control & $\boldsymbol{P}_{\text {-value }}{ }^{\mathbf{a}}$ & Overall $\boldsymbol{P}$-value $^{\mathbf{a}}$ \\
\hline SS & $(5 / 2 I I) 2.4 \%$ & $(I / 205) 0.5 \%$ & $0.27 I$ & $<0.000 I$ \\
\hline MM & $(59 / 2 I I) 28 \%$ & $(54 / 205) 26.3 \%$ & $0.84 I$ \\
\hline LL & $(7 / 2 I I) 3.3 \%$ & $(I / 205) 0.5 \%$ & 0.133 \\
\hline MS & $(82 / 2 I I) 38.8 \%$ & $(I I 9 / 205) 58.1 \%$ & 0.045 & \\
\hline ML & $(58 / 2 I I) 27.5 \%$ & $(30 / 205) 14.6 \%$ & 0.045 & \\
\hline S & $(92 / 422) 2 I .8 \%$ & $(I 2 I / 4 I 0) 29.5 \%$ & $<0.000 I$ & $<0.000 I$ \\
\hline M & $(258 / 422) 6 I .1 \%$ & $(257 / 4 I 0) 62.7 \%$ & 0.980 & \\
\hline L & $(72 / 422) I 7.1 \%$ & $(32 / 4 I 0) 7.8 \%$ & 0.034 & \\
\hline
\end{tabular}

Note: aChi-squared test with $P$-value $<0.05$ is considered significant.

Abbreviation: $\mathrm{p}$-VNTR, promoter variable number tandem repeat.

with $14.6 \%(30 / 205)$ in controls (overall $P$-value $<0.001)$. Allelic and genotypic frequencies for $C Y P 2 C 9 \mathrm{p}-\mathrm{VNTR}$ polymorphism are shown in Table 2.

\section{Association of CYP2C9 p-VNTR polymorphism with warfarin sensitivity during the initiation and stabilization phases of therapy}

There were no statistically significant differences between the doses required to reach the target INR during the initiation and stabilization phases of therapy and $C Y P 2 C 9$ (p-VNTR) genotypes ( $P=0.192$ and 0.966$)$ (Table 3$)$.
Patients were referred to as sensitive, moderate, and resistant, according to the required dose needed to reach the target INR. The sensitive group showed a high frequency of the SS (20\%) and LM (22.4\%) genotypes, while the resistant group showed a higher frequency of the LL genotype (28.6\%) only during the initiation phase of therapy with overall $P$-value $<0.001$, whereas when we compared each separate genotype with these sensitive groups, no significant association was found (Table 4). During the stabilization phase, no significant associations were found neither between the sensitive groups as a general value nor with each separate genotype with overall $P$-value $=0.910($ Table 5$)$. 
Table 3 Association of CYP2C9 p-VNTR polymorphism with variability on required warfarin

\begin{tabular}{|c|c|c|c|c|c|c|c|c|c|c|c|}
\hline \multirow[t]{2}{*}{ Polymorphism } & \multirow[t]{2}{*}{ Genotype } & \multirow{2}{*}{$\begin{array}{l}\text { Initiation } \\
\text { dose }\end{array}$} & \multicolumn{2}{|l|}{$95 \% \mathrm{Cl}$} & \multirow[t]{2}{*}{$P$-value ${ }^{a}$} & \multirow{2}{*}{$\begin{array}{l}\text { Overall } \\
\text {-value }^{a}\end{array}$} & \multirow{2}{*}{$\begin{array}{l}\text { Maintenance } \\
\text { dose }\end{array}$} & \multicolumn{2}{|l|}{$95 \% \mathrm{Cl}$} & \multirow[t]{2}{*}{$P$-value ${ }^{a}$} & \multirow{2}{*}{$\begin{array}{l}\text { Overall } \\
P \text {-value }\end{array}$} \\
\hline & & & $\begin{array}{l}\text { Lower } \\
\text { bound }\end{array}$ & $\begin{array}{l}\text { Upper } \\
\text { bound }\end{array}$ & & & & $\begin{array}{l}\text { Lower } \\
\text { bound }\end{array}$ & $\begin{array}{l}\text { Upper } \\
\text { bound }\end{array}$ & & \\
\hline \multirow[t]{5}{*}{ CYP2C9/p-VNTR } & SS & 33.8600 & 16.4615 & 51.2585 & 0.969 & \multirow[t]{5}{*}{0.192} & 33.1500 & 28.4751 & 94.7751 & 0.982 & \multirow[t]{5}{*}{0.966} \\
\hline & MM & 36.4780 & 33.1357 & 39.8203 & 0.829 & & 38.1206 & 32.2087 & 44.0325 & 0.979 & \\
\hline & LL & 40.6463 & 33.7602 & 47.5325 & I & & 36.0167 & I7.624I & 54.4092 & 0.981 & \\
\hline & LM & \begin{tabular}{|l|}
35.8793 \\
\end{tabular} & 31.1840 & 40.5746 & 0.751 & & 39.2184 & $32.330 \mathrm{I}$ & 46.1068 & 0.998 & \\
\hline & MS & 411.0143 & \begin{tabular}{|l|}
22.6276 \\
\end{tabular} & 59.4010 & 0.751 & & 39.6346 & 34.8483 & 44.4209 & 0.998 & \\
\hline
\end{tabular}

Note: ${ }^{0}$ One-way ANOVA with $P$-value $<0.05$ is considered significant, mean doses.

Abbreviation: $p-V N T R$, promoter variable number tandem repeat.

Table 4 Association of CYP2C9 P-VNTR polymorphism with warfarin sensitivity during the initiation phase of therapy of 2 II cardiovascular patients treated with warfarin

\begin{tabular}{|c|c|c|c|c|c|}
\hline Polymorphism & Genotype & Sensitive & Moderate & Resistance & Overall $P$-value \\
\hline \multirow[t]{10}{*}{$\mathrm{p}-\mathrm{VNTR}$} & SS & (I/5) $20.0 \%$ & (3/5) $60.0 \%$ & (I/5) $20.0 \%$ & \multirow[t]{10}{*}{$<0.001$} \\
\hline & $P$-value ${ }^{\mathrm{a}}$ & 0.76 & 0.62 & 0.76 & \\
\hline & MM & (8/59) $13.6 \%$ & (43/59) $72.9 \%$ & (8/59) $13.6 \%$ & \\
\hline & $P$-value ${ }^{\mathrm{a}}$ & 0.69 & 0.55 & 0.69 & \\
\hline & $\mathrm{LL}$ & (0/0) $0.0 \%$ & (5/7) $71.4 \%$ & (2/7) $28.6 \%$ & \\
\hline & $P$-value ${ }^{\mathrm{a}}$ & 0.27 & 0.92 & 0.32 & \\
\hline & LM & (I3/58) $22.4 \%$ & (37/8) 63.8\% & (8/58) $13.8 \%$ & \\
\hline & $P$-value ${ }^{\mathrm{a}}$ & 0.07 & 0.27 & 0.84 & \\
\hline & MS & $(10 / 82) 12.2 \%$ & (59/82) $71.9 \%$ & $(13 / 82) 15.9 \%$ & \\
\hline & $P$-value ${ }^{\mathrm{a}}$ & 0.32 & 0.53 & 0.84 & \\
\hline
\end{tabular}

Note: a'Chi-squared test with $P$-value $<0.05$ is considered significant.

Abbreviation: $\mathrm{p}-\mathrm{VNTR}$, promoter variable number tandem repeat.

Table 5 Association of CYP2C9 p-VNTR polymorphism with warfarin sensitivity during the stabilization phase of therapy of 132 cardiovascular patients treated with warfarin

\begin{tabular}{|c|c|c|c|c|c|}
\hline Polymorphism & Genotype & Sensitive & Moderate & Resistance & Overall $P$-value \\
\hline \multirow[t]{10}{*}{$\mathrm{p}-\mathrm{VNTR}$} & SS & $0 / 2) 0.0 \%$ & (2/0) $100.0 \%$ & (0/2) $0.0 \%$ & \multirow[t]{10}{*}{0.910} \\
\hline & $P$-value ${ }^{\mathrm{a}}$ & 0.55 & 0.27 & 0.42 & \\
\hline & MM & (6/34) 17.6\% & (20/34) 58.9\% & (8/34) $23.5 \%$ & \\
\hline & $P$-value ${ }^{\mathrm{a}}$ & 0.42 & 0.62 & 0.92 & \\
\hline & $\mathrm{LL}$ & (0/6) $0.0 \%$ & (5/6) 83.3\% & (I/6) $16.7 \%$ & \\
\hline & $P$-value ${ }^{\mathrm{a}}$ & 0.32 & 0.27 & 0.69 & \\
\hline & LM & $(5 / 38) 13.2 \%$ & $(23 / 38) 60.5 \%$ & $(10 / 38) 26.3 \%$ & \\
\hline & $P$-value ${ }^{\mathrm{a}}$ & 0.92 & 0.84 & 0.69 & \\
\hline & MS & (7/52) II.8\% & (32/52) 62.7\% & (I3/52) $25.4 \%$ & \\
\hline & $P$-value ${ }^{\mathrm{a}}$ & 1 & 0.92 & 0.84 & \\
\hline
\end{tabular}

Note: aChi-squared test with $P$-value $<0.05$ is considered significant.

Abbreviation: $\mathrm{p}-\mathrm{VNTR}$, promoter variable number tandem repeat.

\section{Association of CYP2C9 p-VNTR polymorphism with warfarin responsiveness during the initiation and stabilization phases of therapy}

Based on warfarin responsiveness, patients were divided into three groups: poor, good, and ultra-responders. There were no significant differences between the frequencies for the different genotypes among the three groups, neither in the initiation phase (overall $P=0.255$ ) nor throughout the maintenance phase (overall $P=0.350$ ) of therapy (Tables 6 and 7).

There were no significant differences in the CYP2C9 $\mathrm{p}$-VNTR and the value of INR measured at the initial stage of therapy in 211 patients receiving warfarin (overall $P=0.598$ ) nor for INR values measured in 132 patients during the stabilization phase (overall $P=0.466$ ) (Table 8 ). 
Table 6 Association of CYP2C9 p-VNTR polymorphism with response to warfarin during the initiation phase of therapy of 211 cardiovascular patients treated with warfarin

\begin{tabular}{|c|c|c|c|c|c|}
\hline Polymorphism & Genotype & Poor responder & Good responder & Ultra-responder & Overall $P$-value \\
\hline \multirow[t]{10}{*}{$\mathrm{p}$-VNTR } & SS & (2/5) $40.0 \%$ & (3/5) $60.0 \%$ & $(0 / 5) 0.0 \%$ & \multirow[t]{10}{*}{0.255} \\
\hline & $P$-value ${ }^{a}$ & 0.92 & 0.55 & 0.37 & \\
\hline & MM & (27/59) $45.8 \%$ & (27/59) 45.8\% & (5/59) $8.5 \%$ & \\
\hline & $P$-value ${ }^{\mathrm{a}}$ & 0.42 & $\mathrm{I}$ & 0.23 & \\
\hline & LL & $(0 / 0) 0.0 \%$ & (5/7) $71.4 \%$ & (2/7) $28.6 \%$ & \\
\hline & $P$-value ${ }^{a}$ & 0.02 & 0.16 & 0.19 & \\
\hline & LM & $(21 / 58) 36.2 \%$ & (30/8) 5I.7\% & $(7 / 58) 12.1 \%$ & \\
\hline & $P$-value ${ }^{a}$ & 0.27 & 0.23 & 0.84 & \\
\hline & MS & (38/82) 46.3\% & (3I/82) $37.8 \%$ & \begin{tabular}{|l}
$(13 / 82) 15.9 \%$ \\
\end{tabular} & \\
\hline & $P$-value ${ }^{\mathrm{a}}$ & 0.23 & 0.07 & 0.32 & \\
\hline
\end{tabular}

Note: ${ }^{a}$ Chi-squared test with $P$-value $<0.05$ is considered significant.

Abbreviation: $\mathrm{p}-\mathrm{VNTR}$, promoter variable number tandem repeat.

Table 7 Association of CYP2C9 p-VNTR polymorphism with response to warfarin during the stabilization phase of therapy of I32 cardiovascular patients treated with warfarin

\begin{tabular}{|c|c|c|c|c|c|}
\hline Polymorphism & Genotype & Poor responder & Good responder & Ultra-responder & Overall $P$-value ${ }^{a}$ \\
\hline \multirow[t]{10}{*}{$\mathrm{p}$-VNTR } & SS & (0/2) $0.0 \%$ & (2/2) $100.0 \%$ & $(0 / 2) 0.0 \%$ & \multirow[t]{10}{*}{0.350} \\
\hline & $P$-value ${ }^{\mathrm{a}}$ & 0.69 & 0.62 & 0.76 & \\
\hline & MM & (4/34) II.8\% & (26/34) $76.5 \%$ & (4/34) II.8\% & \\
\hline & $P$-value ${ }^{\mathrm{a}}$ & 0.19 & 0.01 & 0.02 & \\
\hline & $\mathrm{LL}$ & $(1 / 6) 16.7 \%$ & $(5 / 6) 83.3 \%$ & $(0 / 6) 0.0 \%$ & \\
\hline & $P$-value ${ }^{a}$ & 0.32 & 0.69 & 0.62 & \\
\hline & LM & (2/38) $5.3 \%$ & (35/38) $92.1 \%$ & (I/38) $2.6 \%$ & \\
\hline & $P$-value ${ }^{\mathrm{a}}$ & 0.62 & 0.42 & 0.48 & \\
\hline & MS & (2/52) $3.8 \%$ & (49/52) $94.2 \%$ & $(1 / 52) 1.9 \%$ & \\
\hline & $P$-value ${ }^{\mathrm{a}}$ & 0.27 & 0.11 & 0.23 & \\
\hline
\end{tabular}

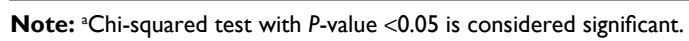

Abbreviation: $\mathrm{p}$-VNTR, promoter variable number tandem repeat.

Table 8 Association of CYP2C9 p-VNTR polymorphism with INR treatment outcome

\begin{tabular}{|c|c|c|c|c|c|c|c|c|c|c|c|}
\hline \multirow[t]{2}{*}{ Polymorphism } & \multirow[t]{2}{*}{ Genotype } & \multirow{2}{*}{$\begin{array}{l}\text { Initiation } \\
\text { INR }\end{array}$} & \multicolumn{2}{|l|}{$95 \% \mathrm{Cl}$} & \multirow[t]{2}{*}{$P$-value ${ }^{a}$} & \multirow{2}{*}{$\begin{array}{l}\text { Overall } \\
P \text {-value }\end{array}$} & \multirow{2}{*}{$\begin{array}{l}\text { Maintenance } \\
\text { INR }\end{array}$} & \multicolumn{2}{|l|}{$95 \% \mathrm{Cl}$} & \multirow{2}{*}{$\begin{array}{l}\text { Upper } \\
\text { bound }\end{array}$} & \multirow{2}{*}{$\begin{array}{l}\text { Overall } \\
P \text {-value }\end{array}$} \\
\hline & & & $\begin{array}{l}\text { Lower } \\
\text { bound }\end{array}$ & $\begin{array}{l}\text { Upper } \\
\text { bound }\end{array}$ & & & & $\begin{array}{l}\text { Lower } \\
\text { bound }\end{array}$ & $\begin{array}{l}\text { Upper } \\
\text { bound }\end{array}$ & & \\
\hline \multirow[t]{5}{*}{ CYP2C9/p-VNTR } & SS & 2.32 & 1.2613 & 3.3787 & 0.477 & \multirow[t]{5}{*}{0.598} & 2.85 & -5.4090 & 11.1090 & 0.997 & \multirow[t]{5}{*}{0.466} \\
\hline & MM & 2.34 & 2.1444 & 2.5454 & 0.969 & & 2.7 & 2.5625 & 2.8464 & 1 & \\
\hline & LL & 3.16 & 2.0133 & 4.3009 & 0.083 & & 2.5 & 2.0450 & 2.9550 & 0.825 & \\
\hline & LM & 2.48 & 2.3006 & 2.6649 & 0.253 & & 2.64 & 2.4986 & 2.7762 & 0.998 & \\
\hline & MS & 2.48 & 2.3138 & 2.6496 & 0.232 & & 2.73 & 2.6447 & 2.8245 & 0.934 & \\
\hline
\end{tabular}

Note: ane-way ANOVA with $P$-value $<0.05$ is considered significant, mean INR.

Abbreviations: $p$-VNTR, promoter variable number tandem repeat; INR, international normalized ratio.

\section{Discussion}

In this study, we investigated and characterized the p-VNTR polymorphism of $C Y P 2 C 9$ gene and its association with increased risk of cardiovascular disease and with warfarin sensitivity and responsiveness during the initiation and stabilization phases of warfarin therapy in a Jordanian population.

Sconce et al study exhibited that patients carrying CYP2C9 variants have an altered ability to metabolize warfarin, resulting in an effect in the clearance of S-active warfarin metabolite and, therefore, alter the dose required to reaching the therapeutic INR. ${ }^{31}$ It has been extensively demonstrated that VNTRs affect gene expression ${ }^{23,24,26}$ and are associated with the risk of diseases such as Alzheimer's disease. ${ }^{27,28}$

To our knowledge, although several SNP/haplotype studies of the CYP2C9 promoter have been identified, none of 
them demonstrate the $C Y P 2 C 9 \mathrm{p}$-VNTR polymorphism and its effect on warfarin clearance, except Wang et al study. ${ }^{20,32-34}$ Similarly, we evaluated the frequency of p-VNTR polymorphisms and their genetic associations with cardiovascular diseases, and this study revealed a significant association between these polymorphisms and the risk of developing cardiovascular disease. Allelic and genotypic frequencies differ significantly between patients and controls. We found the frequency of L allele was $17.1 \%(72 / 422)$ in patients compared with $7.8 \%(32 / 410)$ in controls $(P<0.001)$ (Table 2$)$.

To our knowledge, no studies demonstrate the relation between these polymorphisms and the risk of cardiovascular disease. Wang et al demonstrated that the p-VNTR-S allele reduces promoter activity of the CYP2C9 enzyme in human liver. ${ }^{20}$ It has also been reported that $\mathrm{p}$-VNTR-S allele is associated with a $25 \%-60 \%$ reduction in $C Y P 2 C 9$ mRNA expression compared with p-VNTR-M or p-VNTR-L alleles. ${ }^{20}$ Consistent with these results, our results indicate that the p-VNTR genotype significantly affected warfarin sensitivity during the initiation of therapy, which could be the result of enzyme deactivation activity. We found that $20 \%$ of the warfarin-sensitive patients were homozygous for the short p-VNTR-S allele and 12.2\% were heterozygous, p-VNTR-M/p-VNTR-S; therefore, these patients required a lower dose to achieve a therapeutic INR. Homozygous p-VNTR-S genotypic frequency in our population $(2.4 \%)$ is lesser than that in African-American population (5.1\%). ${ }^{20}$ Finally, during the stabilization phase of therapy, no significant differences were found between these groups and their genotype frequencies (Tables 4 and 5).

To our knowledge, no studies have evaluated the association between $C Y P 2 C 9$ p-VNTR polymorphism and the response to warfarin using the INR outcome measures. In the current study, no association between this polymorphism and the response to warfarin during the initiation and maintenance phases confirmed the therapy (Tables 6 and 7). Wang et al demonstrated that the $\mathrm{p}$-VNTR-S polymorphism is present in high linkage disequilibrium with the CYP2C9*3 lossof-function allele, so the effect of p-VNTR-S on warfarin metabolism appears to be restricted. Therefore, $p-V N T R-S$ is not assessed as a biomarker for warfarin dosing and further studies are required to confirm its independent effects on warfarin metabolism. ${ }^{20}$

\section{Conclusion}

Our data show a significant association between the $C Y P 2 C 9$ p-VNTR polymorphism and the risk of cardiovascular disease as well as the association between this polymorphism and the sensitivity to warfarin during the initiation phase of treatment. However, no association was found between this polymorphism and warfarin responsiveness or between the INR result and the required warfarin dose to reach the therapeutic INR, either during the initiation or the maintenance of therapy. To confirm our results, further analyses with a larger number of samples and different populations are required.

\section{Acknowledgment}

This work was supported by the Deanship of Research at Jordan University of Science and Technology under grant number 207/2017.

\section{Disclosure}

The authors report no conflicts of interest in this work.

\section{References}

1. Ansell J, Hirsh J, Hylek E, Jacobson A, Crowther M, Palareti G. Pharmacology and management of the vitamin $\mathrm{K}$ antagonists. Chest. 2008;133(6):160S-198S.

2. Kaminsky LS, Zhang ZY. Human P450 metabolism of warfarin. Pharmacol Ther. 1997;73(1):67-74.

3. Wallin R, Hutson SM. Warfarin and the vitamin K-dependent gammacarboxylation system. Trends Mol Med. 2004;10(7):299-302.

4. King CR, Deych E, Milligan P, et al. Gamma-glutamyl carboxylase and its influence on warfarin dose. Thromb Haemost. 2010;104(4):750-754.

5. Anticoagulants in the Secondary Prevention of Events in Coronary Thrombosis (ASPECT) Research Group. Effect of long-term oral anticoagulant treatment on mortality and cardiovascular morbidity after myocardial infarction*1. The Lancet. 1994;343(8896):499-503.

6. The Stroke Prevention in Atrial Fibrillation Investigators. Bleeding during antithrombotic therapy in patients with atrial fibrillation. Arch Intern Med;156(4):409-416.

7. Fihn S. Risk factors for complications of chronic anticoagulation: a multicenter study. Ann Intern Med. 1993;118(7):511-520.

8. Stroke Prevention in Atrial Fibrillation Investigators. Adjusted-dose warfarin versus low-intensity, fixed-dose warfarin plus aspirin for high-risk patients with atrial fibrillation: Stroke Prevention in Atrial Fibrillation III randomised clinical trial. Lancet 1996;348(9028):633-638.

9. Linkins L-A, Choi PT, Douketis JD. Clinical impact of bleeding in patients taking oral anticoagulant therapy for venous thromboembolism: a meta-analysis. Ann Intern Med. 2003;139(11):893-900.

10. Gage BF, Lesko LJ. Pharmacogenetics of warfarin: regulatory, scientific, and clinical issues. J Thromb Thrombolysis. 2008;25(1):45-51.

11. Loebstein R, Dvoskin I, Halkin H, et al. A coding VKORC1 Asp36Tyr polymorphism predisposes to warfarin resistance. Blood. 2007;109(6): 2477-2480.

12. Gage BF, Milligan P, Banet G, Duncan J, Mcleod H, Mcleod HL. Use of pharmacogenetics and clinical factors to predict the maintenance dose of warfarin. Thromb Haemost. 2004;91(1):87-94.

13. Coumadin $₫$ (warfarin) [package insert]. Princeton, NJ: Bristol-Myers Squibb; 2010:5.

14. Wadelius M, Chen LY, Eriksson N, et al. Association of warfarin dose with genes involved in its action and metabolism. Hum Genet. 2007;121(1):23-34.

15. Miners JO, Birkett DJ. Cytochrome P4502C9: an enzyme of major importance in human drug metabolism. Br J Clin Pharmacol. 1998;45(6):525-538.

16. Rendic S. Summary of information on human CYP enzymes: human P450 metabolism data. Drug Metab Rev. 2002;34(1-2):83-448. 
17. Zhou S-F, Zhou Z-W, Yang L-P, Cai J-P. Substrates, inducers, inhibitors and structure-activity relationships of human cytochrome P450 2C9 and implications in drug development. Curr Med Chem. 2009;16(27):3480-3675.

18. Sim SC, Ingelman-Sundberg M. The Human Cytochrome P450 (CYP) Allele Nomenclature website: a peer-reviewed database of CYP variants and their associated effects. Hum Genomics. 2010;4(4):278-281.

19. Delozier T, Lee S-C, Coulter SJ, Goh BC, Goldstein JA. Functional characterization of novel allelic variants of CYP2C9 recently discovered in Southeast Asians. J Pharmacol Exp Ther. 2005;315(3):1085-1090.

20. Wang D, Sun X, Gong Y, et al. CYP2C9 promoter variable number tandem repeat polymorphism regulates $\mathrm{mRNA}$ expression in human livers. Drug Metab Dispos. 2012;40(5):884-891.

21. Lesch KP, Balling U, Gross J, et al. Organization of the human serotonin transporter gene. J Neural Transm Gen Sect. 1994;95(2):157-162.

22. Contente A, Dittmer A, Koch MC, Roth J, Dobbelstein M. A polymorphic microsatellite that mediates induction of PIG3 by p53. Nat Genet. 2002;30(3):315-320.

23. Albanèse V, Biguet NF, Kiefer H, Bayard E, Mallet J, Meloni R. Quantitative effects on gene silencing by allelic variation at a tetranucleotide microsatellite. Hum Mol Genet. 2001;10(17):1785-1792.

24. Borrmann L, Seebeck B, Rogalla P, Bullerdiek J. Human HMGA2 promoter is coregulated by a polymorphic dinucleotide (TC)-repeat. Oncogene. 2003;22(5):756-760.

25. Amador ML, Oppenheimer D, Perea S, et al. An epidermal growth factor receptor intron 1 polymorphism mediates response to epidermal growth factor receptor inhibitors. Cancer Res. 2004;64(24):9139-9143.

26. Donninger H, Cashmore TJ, Scriba T, et al. Functional analysis of novel SLC11A1 (NRAMP1) promoter variants in susceptibility to HIV-1. $J$ Med Genet. 2004;41(4):e49.
27. Heshmati Y, Mirabzadeh A, Feizzade G, et al. A novel polymorphic purine complex at the $1.5 \mathrm{~kb}$ upstream region of the human caveolin-1 gene and risk of Alzheimer's disease; extra-short alleles and accumulated allele homozygosity. Am J Med Genet B Neuropsychiatr Genet. 2009;150B(2):248-253.

28. Zarif Yeganeh M, Mirabzadeh A, Khorram Khorshid HR, et al. Novel extreme homozygote haplotypes at the human caveolin 1 gene upstream purine complex in sporadic Alzheimer's disease. Am J Med Genet B Neuropsychiatr Genet. 2010;153B(1):347-349.

29. Klein TE, Altman RB, Eriksson N, et al. Estimation of the warfarin dose with clinical and pharmacogenetic data. $N$ Engl J Med. 2009;360(8):753-764.

30. Higashi MK, Veenstra DL, Kondo LM, et al. Association between CYP2C9 genetic variants and anticoagulation-related outcomes during warfarin therapy. JAMA. 2002;287(13):1690-1698.

31. Sconce EA, Khan TI, Wynne HA, et al. The impact of CYP2C9 and VKORC1 genetic polymorphism and patient characteristics upon warfarin dose requirements: proposal for a new dosing regimen. Blood. 2005;106(7):2329-2333.

32. Shintani M, Ieiri I, Inoue $\mathrm{K}$, et al. Genetic polymorphisms and functional characterization of the 5'-flanking region of the human CYP2C9 gene: in vitro and in vivo studies. Clin Pharmacol Ther. 2001;70(2): 175-182.

33. Takahashi H, Ieiri I, Wilkinson GR, et al. 5'-flanking region polymorphisms of CYP2C9 and their relationship to S-warfarin metabolism in white and Japanese patients. Blood. 2004;103(8):3055-3057.

34. Kramer MA, Rettie AE, Rieder MJ, Cabacungan ET, Hines RN. Novel CYP2C9 promoter variants and assessment of their impact on gene expression. Mol Pharmacol. 2008;73(6):1751-1760.
Pharmacogenomics and Personalized Medicine

\section{Publish your work in this journal}

Pharmacogenomics and Personalized Medicine is an international, peerreviewed, open access journal characterizing the influence of genotype on pharmacology leading to the development of personalized treatment programs and individualized drug selection for improved safety, efficacy and sustainability. This journal is indexed on the American Chemical

\section{Dovepress}

Society's Chemical Abstracts Service (CAS). The manuscript management system is completely online and includes a very quick and fair peer-review system, which is all easy to use. Visit http://www.dovepress. $\mathrm{com} /$ testimonials.php to read real quotes from published authors. 